\title{
PERBANDINGAN TEKNIK MASSAGE EFFLEURAGE (MENGGOSOK) DENGAN TEKNIK MASSAGE SHAKING (GONCANGAN) PADA SEGMEN TUNGKAI BAWAH TERHADAP PENURUNAN KADAR ASAM LAKTAT SETELAH LATIHAN FISIK ANAEROBIK
}

\author{
Abdul Syafei, Hardi Darmawan, Theodorus \\ Program Studi Megister Ilmu Biomedik, Fakultas Kedokteran, Universitas Sriwijaya \\ abdulsyafei86@yahoo.co.id
}

\begin{abstract}
ABSTRAK
Aktivitas fisik dengan intensitas tinggi dapat menyebabkan terjadinya peningkatan kadar asam laktat dalam darah maupun otot. Peningkatan kadar asam laktat, merupakan salah satu faktor penyebab terjadinya kelelahan. Untuk mengurangi kelelahan dilakukan dengan massage yang merupakan manipulasi sederhana dengan mengusap tubuh yang sakit pada struktur jaringan lunak yang dapat menenangkan serta mengurangi stress psikologis. Tujuan penelitian adalah untuk mengetahui perbandingan teknik massage effleurage dengan teknik massage shaking terhadap penurunan kadar asam laktat setelah aktivitas fisik anaerobik. Penelitian uji klinik berpembanding dalam bentuk open lable dengan rancangan pretest-postest design. Subjek penelitian mahasiswa FKIP jurusan pendidikan olahraga universitas sriwijaya palembang berjumlah 51 responden yang memenuhi kriteria inklusi, dibagi menjadi tiga kelompok yaitu kelompok teknik massage effleurage, kelompok teknik massage shaking, dan kelompok kontrol yang masing-masing kelompok berjumlah 17 responden. Pada masing-masing kelompok dilakukan pemeriksaan laktat awal (pre test), kemudian setelah aktivitas 5 menit dilakukan pemeriksaan kadar asam laktat (post test), dan dilakukan massage pada kelompok perlakuan sedangkan kelompok kontrol tidak dilakukan massage. setelah 20 menit dilakuan pemeriksaan kadar asam laktat (post massage). Hasil uji statistik menunjukkan nilai rerata kadar asam laktat sebelum aktivitas pada kelompok teknik massage effluarage (menggosok) yaitu $3,406 \pm 0,96$ sedangkan sesudah aktivitas yaitu $8,959 \pm 1,24$. Rerata kadar asam laktat sebelum aktivitas pada kelompok teknik massage shaking (goncangan) yaitu $3,241 \pm 0,78$ sedangkan sesudah aktivitas yaitu $8,276 \pm 0,77$. Rerata kadar asam laktat sebelum aktivitas pada kelompok kontrol yaitu $3,406 \pm 0,96$ sedangkan sesudah aktivitas yaitu $8,959 \pm 1,24$. Sedangkan pada kelompok setelah perlakuan teknik massage effluarage (menggosok) didapat nilai yaitu $3,800 \pm 1,07$ dan pada teknik massage shaking (goncangan) didapat nilai yaitu 4,065 $\pm 0,56$ hal ini menunjukkan bahwa tidak ada perbedaan bermakna antara teknik massage effluarage (menggosok) dengan teknik massage shaking (goncangan) dengan $p$ value 0,416 ( $p>0,05$ ). Dapat disimpulkan bahwa massage effleurage dan massage shaking sama-sama dapat menurunkan kadar asam laktat setelah aktivitas fisik anaerobik.
\end{abstract}

Kata Kunci : Aktivitas fisik, Kadar asam laktat, Massage. 


\section{PENDAHULUAN}

Aktivitas fisik dengan intensitas tinggi akan menyebabkan otot berkontraksi secara anaerobic yang membutuhkan penyediaan energi (ATP) melalui proses glikolisis anaerobik atau sistem asam laktat. (Bompa, 1990; Fox, 1993).

Peningkatan kadar asam laktat menunjukkan terjadi peningkatan metabolisme untuk memenuhi kebutuhan energi, yang berdampak pada menurunnya kekuatan kontraksi otot dan menurunkan jumlah ion kalsium pada troponin selama proses kontraksi otot, sehingga terjadi kelelahan dan terasa nyeri pada otot (Bangso,1997).

Kelelahan merupakan suatu proses alami yang terjadi apabila seseorang sudah melakukan aktivitas, sehingga dapat mempengaruhi performa fisik, untuk menanggulangi hal tersebut membutuhkan cara -cara dalam mempercepat pemulihan kembali dari rasa lelah. (Sugiharto, 2012)

Mekanisme pemulihan laktat darah dan otot sangat dipengaruhi oleh aktivitas fisik maksimal, proses Eliminasi asam laktat dan pemulihan asam laktat penting untuk meningkatkan aliran darah, meningkatkan cardiac output, meningkatkan transport laktat, sehingga cepat membentuk energi kembali (Clark, 1997). Salah satu cara yang dapat membantu mempercepat proses eliminasi laktat dan pemulihan laktat yaitu dilakukan dengan massage.

Massage merupakan manipulasi sederhana dengan mengusap tubuh yang sakit pada struktur jaringan lunak yang dapat menenangkan serta mengurangi stress psikologis dengan meningkatkan hormone. Adapun teknik massage yang digunakan pada daerah ektremitas dengan cara gerakan menggosok tubuh (eufleurage), perasan (petrissage), shaking, walken dan terakhir ditutup dengan eufleurage. Penelitian yang dilakukan oleh Goats (1994) membuktikan, gerakan effleurage pada massage dapat meningkatkan aliran darah pada otot - otot besar, sehingga dapat menurunkan kadar asam laktat.

Tujuan penelitian ini adalah untuk mengetahui perbandingan teknik massage effleurage dengan teknik massage shaking yang dilakukan pada segmen tungkai bawah terhadap penurunan kadar asam laktat setelah aktivitas fisik anaerobik. Dalam penelitian ini diharapkan dapat memberikan informasi bagi masyarakat dalam beraktivitas untuk dapat melakukan pemulihan dengan massage sehingga terhindar dari cedera.

\section{METODE PENELITIAN}

Jenis penelitian ini adalah penelitian uji klinik berpembanding dalam bentuk open lable dengan rancangan Pretest-Postest Design. Sampel penelitian berjumlah 51 orang yang dibagi menjadi tiga kelompok yaitu kelompok teknik massage effleurage, kelompok teknik massage shaking, dan kelompok kontrol yang masing-masing kelompok berjumlah 17 orang. Pada masing-masing kelompok dilakukan pemeriksaan laktat awal (pre test), kemudian setelah aktivitas 5 menit dilakukan pemeriksaan kadar asam laktat (post test), dan dilakukan massage pada kelompok perlakuan sedangkan kelompok kontrol tidak dilakukan massage. setelah 20 menit dilakukan pemeriksaan kadar asam laktat (post massage). Pelaksanaan penelitian ini di lapangan olahraga Universitas Sriwijaya Palembang dengan lari sprint $2 \times 60$ meter. 
Data yang dikumpulkan dalam penelitian ini meliputi pengambilan spesimen darah perifer dilakukan sebelum dan setelah aktivitas fisik dengan lari sprint $2 \times 60$ meter lalu dilakukan massage dengan teknik effluerage dan teknik shaking selama 20 menit. Analisis data dilakukan dengan menggunakan Uji Normalitas, dependent t-test dan uji Anova pos hock dengan tingkat kemaknaan 95\% ( $\alpha>0,05)$. Proses ini menggunakan sistem komputerisasi program SPSS versi 19 for windows dengan taraf signifikansi $p>0,05$.

Tabel 1. Karakteristik Subyek.

\begin{tabular}{|c|c|c|c|c|c|}
\hline \multirow[t]{2}{*}{ Karakteristik } & \multirow{2}{*}{$\mathrm{N}$} & \multicolumn{3}{|c|}{ Kelompok } & \multirow{2}{*}{$p^{*}$} \\
\hline & & $\begin{array}{l}\text { Effluarage } \\
\text { rerata } \pm \text { SD }\end{array}$ & $\begin{array}{c}\text { Shaking } \\
\text { Rerata } \pm \text { SD }\end{array}$ & $\begin{array}{c}\text { Kontrol } \\
\text { Rerata } \pm \text { SD }\end{array}$ & \\
\hline Umur (tahun) & & $18,4 \pm 0,800$ & $18,5 \pm 0,514$ & $19,0 \pm 1,323$ & 0,330 \\
\hline I M T $\left(\mathrm{kg} / \mathrm{m}^{2}\right)$ & & $17,6 \pm 1,853$ & $17,7 \pm 1,774$ & $19,1 \pm 2,25$ & 0,531 \\
\hline Nadi (menit) & & $79,7 \pm 2,93$ & $79,6 \pm 0,786$ & $80,3 \pm 1,27$ & 0,062 \\
\hline Pernafasan (menit) & 51 & $20,8 \pm 1,01$ & $20,4 \pm 1,06$ & $20,3 \pm 0,786$ & 0,120 \\
\hline Sistol $(\mathrm{mmHg})$ & & $125,2 \pm 5,14$ & $122,3 \pm 5,62$ & $125,8 \pm 15,63$ & 0,085 \\
\hline Diastol (mmHg) & & $77,6 \pm 4,37$ & $78,5 \pm 3,29$ & $77,5 \pm 4,33$ & 0,142 \\
\hline
\end{tabular}

\section{$p^{\star}:$ Levene's test, $p \geq 0,05$}

Pada karakteristik subjek penelitian ini menunjukkan tidak ada perbedaan yang signifikan $(p>0,05)$ sehingga subjek penelitian ini terlihat homogen dan dapat dibandingkan.

Menurut peneliti aktivitas fisik yang dilakukan secara anaerobik dapat terjadi peningkatan tekanan darah, nadi, frekuensi pernafasan, IMT dan sistol diastol. Hal ini menunjukkan bahwa respon pada subjek penelitian ketiga kelompok tersebut dapat dikatakan sama atau homogen.

Menurut Adam (2002) usia sangat berpengaruh sekali terhadap proses latihan. Pada usia ini 18-20 tahun merupakan usia pertumbuhan dan secara fisiologis laki-laki dewasa memiliki hormon androgen yang

\section{HASIL DAN PEMBAHASAN}

Berdasarkan hasil pengumpulan data pada karakteristik subjek penelitian yang meliputi variabel umur, indeks massa tubuh (IMT), nadi, pernafasan, sistol, dan diastol pada kelompok perlakuan dan kelompok kontrol menunjukkan tidak ada perbedaan yang bermakna $(p>0,05)$ pada kedua kelompok tersebut. 
Uji Normalitas Kadar Asam Laktat

Uji normalitas data dilakukan untuk melihat apakah data kadar asam laktat sebelum perlakuan dan setelah perlakuan berdistribusi normal atau tidak. Apabila data terdistribusi normal maka analisis uji t-test menggunakan uji parametrik sedangkan jika data tidak terdistribusi normal maka analisis yang digunakan uji non parametrik. Hasil analisis dapat dilihat sebagai berikut:

Tabel 2. Uji Normalitas Kadar Asam Laktat Sebelum Aktivitas pada Kelompok Massage Effleuarage dengan Kelompok Massage Shaking dan Kelompok Kontrol.

\begin{tabular}{ccccc}
\hline \multirow{2}{*}{ Variabel } & \multicolumn{3}{c}{ Kelompok } & \multirow{2}{*}{ P $^{*}$} \\
\cline { 2 - 4 } & $\begin{array}{c}\text { Massage effluarage } \\
\text { Rerata } \pm S D\end{array}$ & $\begin{array}{c}\text { Massage shaking } \\
\text { Rerata } \pm \text { SD }\end{array}$ & $\begin{array}{c}\text { Kontrol } \\
\text { Rerata } \pm S D\end{array}$ & \\
\hline Kadar asam laktat & $3,406 \pm 0,96$ & $3,241 \pm 0,78$ & $3,288 \pm 0,62$ & 0,314 \\
\hline
\end{tabular}

Levene's, $p>0,05$

Berdasarkan hasil uji normalitas kadar asam laktat sebelum ativitas menunjukkan bahwa pada kelompok massage effleuarage nilai rata-rata $3,406 \pm 0,96$ dan pada kelompok massage shaking $3,241 \pm 0,78$ sedangkan kelompok kontrol $3,288 \pm 0,62$ dengan nilai $p$ value $=0,314$. Secara statistik hal ini menunjukkan bahwa kadar asam laktat sebelum aktivitas berdistribusi normal $(p \geq 0,05)$.

Tabel 3. Rerata Kadar Asam Laktat Sebelum dan Sesudah Aktivitas

\begin{tabular}{|c|c|c|c|c|c|}
\hline \multirow[b]{2}{*}{ No. } & \multirow[b]{2}{*}{ Kelompok } & \multirow[b]{2}{*}{$\mathbf{N}$} & \multicolumn{2}{|c|}{ Kadar Asam Laktat } & \multirow[b]{2}{*}{$P^{*}$} \\
\hline & & & $\begin{array}{c}\text { Sebelum } \\
\text { aktivitas } \\
\text { Mean } \pm \text { SD }\end{array}$ & $\begin{array}{c}\text { Sesudah } \\
\text { aktivitas } \\
\text { Mean } \pm \text { SD }\end{array}$ & \\
\hline 1 & Massage Effleurage & 17 & $3,406 \pm 0,96$ & $8,959 \pm 1,24$ & \\
\hline 2 & Massage Shaking & 17 & $3,241 \pm 0,78$ & $8,276 \pm 0,77$ & 0,000 \\
\hline 3 & Kontrol & 17 & $3,288 \pm 0,62$ & $8,524 \pm 1,25$ & \\
\hline
\end{tabular}

$\mathbf{P}^{*}$ uji t berpasangan, $\mathrm{p}<0,05$

Berdasarkan hasil tabel didapatkan bahwa perbedaan rerata kadar asam laktat sebelum dan sesudah aktivitas pada kelompok massage effleurage, massage shaking, dan kelompok kontrol dengan nilai $p$ value 0,000 $(p<0,05)$, ini artinya secara statistik terdapat perbedaan yang bermakna di antara 3 kelompok tersebut.Hal ini menunjukkan bahwa adanya peningkatan kadar asam laktat sebelum aktivitas dansesudah aktivitas fisik 5menit yang dilakukan. Pada penelitian Purnomo (2011) menunjukkan bahwa rerata kadar asam laktat darah sebelum aktivitas submaksimal adalah 2,282 $\mathrm{mmol} / \mathrm{l}$, dan setelah aktivitas 5 menit terjadi peningkatan kadar asam laktat dengan nilai $7,936 \mathrm{mmol} / \mathrm{l}$.

Peningkatan kadar asam laktat terjadi setelah aktivitas fisik submaksimal 5 menit, dimana kecepatan dan daya tahan menjadi sangat dominan dalam menentukan 
keberhasilan aktivitas latihan seseorang. Fox (1993) menyatakan bahwa puncak akumulasi kadar asam laktat darah terjadi pada 5 menit istirahat setelah latihan. Peningkatan terjadi karena kadar asam laktat yang terbentuk selama aktivitas fisik baru dapat berdifusi ke dalam darah setelah 5 menit, oleh karena itu kadar asam laktat darah meningkat pada waktu tersebut (Guyton,2004).

Peningkatan kadar asam laktat setelah aktivitas fisik terjadi dikarenakan tubuh membutuhkan banyak energi sehingga berdampak pada menurunnya kekuatan kontraksi otot dan daya ikat ion $\mathrm{Ca}++$ pada troponin, dan meningkatnya daya ikat retikulum sarkoplasmik terhadap ion $\mathrm{Ca}++$ yang menurunkan jumlah ion kalsium pada troponin selama proses kontraksi otot, sehingga terjadi kelelahan dan terasa nyeri pada otot (Kumaidah, 2002).

Tabel 4. Perbedaan Rerata Kadar Asam

Laktat Sebelum dan Sesudah di Massage.

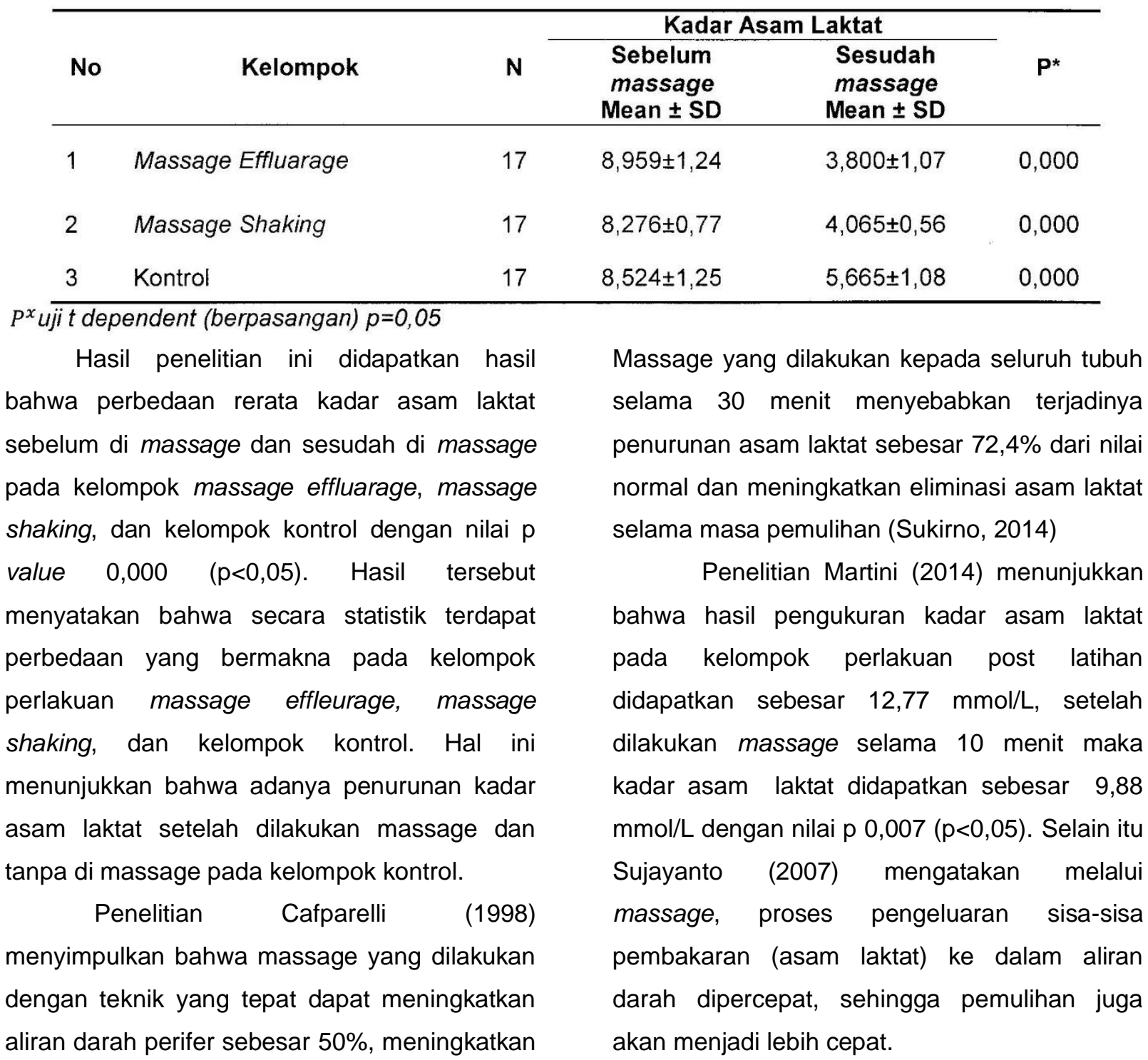

jumlah sel eritrosit $7 \%$, sehingga kinerja dan waktu pemulihan dapat terjadi lebih baik. 
Tabel 5. Perbandingan kadar asam laktat setelah dilakukan masssage pada kelompokteknik effluarage dan teknik massage shakingdengan kelompok kontrol tanpa massage

\begin{tabular}{clccc}
\hline \multicolumn{1}{c}{ Kelompok } & N & $\begin{array}{c}\text { Kadar Asam Laktat } \\
\text { Mean } \pm \text { SD }\end{array}$ & $\mathbf{P}^{*}$ \\
\hline 1 & $\begin{array}{l}\text { Teknik Massage Effluarage vs } \\
\text { Teknik massage shaking }\end{array}$ & 17 & $3,800 \pm 1,07$ vs $4,065 \pm 0,56$ & 0,376 \\
2 & $\begin{array}{l}\text { Teknik Massage effleurage vs } \\
\text { Kontrol }\end{array}$ & 17 & $3,800 \pm 1,07$ vs $5,665 \pm 1,08$ & 0,000 \\
3 & $\begin{array}{l}\text { Teknik massage shaking vs } \\
\text { Kontrol }\end{array}$ & 17 & $4,065 \pm 0,56$ vs $5,665 \pm 1,08$ & 0,000 \\
\hline
\end{tabular}

$P^{\star}$ Uji t independent (tidak berpasangan) $(p<0,05)$

Hasil penelitian ini didapatkan bahwa

massage secara langsung dapat meningkatkan terdapat perbedaan yang bermakna kadar asam aliran vena dikulit serta meningkatkan aliran laktat pada kelompok perlakuan (massage effleurage dan massage shaking) dengan kelompok kontrol $(p<0,05)$. Rerata kadar asam laktat pada kelompok perlakuan menunjukkan bahwa, nilai kadar asam laktat pada teknik massage effleurage $(3,800 \pm 1,07)$ dan teknik massage shaking $(4,065 \pm 0,56)$ lebih rendah dibandingkan dengan kelompok kontrol $(5,665 \pm 1,08)$. Hal ini menunjukkan bahwa, perlakuan di massage selama 20 menit lebih cepat menurunkan kadar asam laktat, dibandingkan dengan tidak di beri perlakuan (pemulihan pasif) 20 menit setelah aktivitas fisik anaerobik.

Hal ini sejalan dalam penelitian Bahartresna (2005) massageseluruh tubuh selama 30 menit menyebabkan terjadinya penurunan asam laktat sebesar $72,4 \%$ dan meningkatkan eliminasi asam laktat selama masa pemulihan setelah latihan fisik intensitas tinggi. Hal ini merupakan bahwa tindakan massage dapat membantu menurunkan tekanan darah dan meningkatkan jangkauan gerak sendi serta mengurangi rasa nyeri. Dubrouvsky (1990). Menjelaskan balik vena. Meningkatnya aliran vena ini akan membantu secara efisien pengembalian darah kejantung, serta membantu mengalirkan asam laktat yang tertimbun dalam otot.

Sedangkan pada kelompok perlakuan teknik massage effleurage dengan teknik massage shaking didapatkan hasil uji statistik bahwa, tidak terdapat perbedaan yang bermakna $(p>0,05)$. Rerata kadar asam laktat pada kedua kelompok menunjukkan bahwa, nilai kadar asam laktat setelah 20 menit di massage pada kelompok teknik massage effleurage $(3,800 \pm 1,07)$ lebih rendah dibandingkan dengan kelompok teknik massage shaking $(4,065 \pm 0,56)$. Hal ini menunjukkan bahwa teknik massage effleurage lebih cepat menurunkan kadar asam laktat di bandingkan dengan teknik massage shaking.

Menurut peneliti, pemulihan yang dilakukan dengan teknik massage effleurage dan teknik massage shaking sama-sama dapat menurunkan kadar asam laktat setelah aktivitas fisik anaerobik, karena pada teknik massage effleurage dan teknik shaking dapat meningkatkan sirkulasi darah, mempercepat 
pembuangan zat sisa pembakaran, serta merelaksasikan otot, sehingga dapat mempercepat eliminasi kadar asam laktat darah dalam otot

Berdasarkan prosedur massage teknik effleurage yang dilakukan dengan menggunakan seluruh permukaan telapak tangan dan jari-jari untuk menggosok daerah tubuh tertentu dengan tujuan aplikasi ini adalah memperlancar peredaran darah dan cairan getah bening (limfe), sehingga asam laktat dapat terserap mengikuti peredaran darah balik (vena). Sedangkan pada prosedur teknik massage shaking dilakukan dengan menggoncang - goncangkan sekelompok otot dengan jari dan telapak tangan atau dengan mengaitkan pada otot yang akan digoncang secara berurutan antara tangan kanan dan kiri yang bertujuan untuk merelaksasikan otot, merangsang syaraf motorik, mempercepat aliran darah serta untuk mempercepat pembuangan sisa pembakaran yang masih tertinggal pada jaringan otot tersebut (Sukirno, 2015).

Tabel 6. Uji Kesesuaian Efektivitas Kadar Asam Laktat pada kelompok perlakuan Teknik Massage Effluarage dan Teknik Massage Shaking dengan kelompok Kontrol

\begin{tabular}{llll}
\hline Variabel & $\begin{array}{l}\text { Teknik Massage } \\
\text { Effluarage }\end{array}$ & $\begin{array}{l}\text { Teknik Massage } \\
\text { Shaking }\end{array}$ & Kontrol \\
\hline $\begin{array}{l}\text { Teknik Massage Effluarage } \\
\text { Teknik Massage Shaking }\end{array}$ & 0,416 & 0,416 & 0,000 \\
Kontrol & 0,000 & & 0,000 \\
\hline
\end{tabular}

Post HoC $p<0,05$

Hasil uji post-hoc menunjukkan bahwa pada teknik massage effluarage dengan teknik massage shaking secara statistik tidak ada perbedaan yang bermakna di antara kedua teknik tersebut dengan nilai $p=0,416$, ini artinya teknik effluarage maupun teknik shaking samasama efektif untuk menurunkan kadar asam laktat. Sedangkan pada teknik effluarage serta teknik shaking dengan kelompok kontrol menunjukkan nilai $p=0,000$, ini artinya bahwa teknik shaking maupun effluarage memang lebih efektif dalam menurunkan kadar asam laktat dibandingkan dengan kelompok kontrol (non massage).

Masase merupakan manipulasi dari struktur jaringan lunak yang dapat menenangkan serta mengurangi stress psikologis dengan meningkatkan hormonmorphin endogen seperti endorphin, enkefalin dan dinorfin sekaligus menurunkan kadar stress hormon seperti hormon cortisol, norepinephrine dan dopamine (Best etal. 2008: 446). Secara fisiologis, masase terbukti dapat menurunkan denyut jantung,meningkatkan tekanan darah, meningkatkan sirkulasi darah dan limfe, mengurangi ketegangan otot, meningkatkan jangkauan gerak sendi serta mengurangi nyeri(Callaghan, 1993)

Dodd,et all (1983) dan Lee dan Kim (1998) mengemukakan bahwa massage superficial yang dilakukan oleh ahlinya pada otot yang telah bekerja maksimal atau pada seluruh tubuh dapat memberikan efek yang dapat menurunkan kadar asam laktat.

Hal yang sama juga dilakukan penelitian oleh Arko,dkk (1983) yang dikutip oleh Corrigan (1997), mengatakan bahwa 
massage juga dapat meningkatkan kosentrasi pada kreatine kinase, laktat dehydrogenase dalam sel otot. Pada penelitian lainnya yang dilakukan oleh Kisner dan Lyrin (1996) mengatakan bahwa massage dapat mempercepat eliminasi asam laktat atau pengeluaran dari efek vasodilatator setelah latihan fisik anaerobik, sehingga individu merasa nyaman dengan penampilan performance yang baik.

\section{SIMPULAN DAN SARAN SIMPULAN}

Berdasarkan uraian hasil penelitian dan pembahasan dapat disimpulkan bahwa :

1. Rerata kadar asam laktat sebelum aktivitas pada kelompok teknik massage effluarage (menggosok) yaitu $3,406 \pm 0,96$ sedangkan sesudah aktivitas yaitu $8,959 \pm 1,24$. Rerata kadar asam laktat sebelum aktivitas pada kelompok teknik massage shaking (goncangan) yaitu $3,241 \pm 0,78$ sedangkan sesudah aktivitas yaitu $8,276 \pm 0,77$. Rerata kadar asam laktat sebelum aktivitas pada kelompok kontrol yaitu 3,406 $\pm 0,96$ sedangkan sesudah aktivitas yaitu $8,959 \pm 1,24$

2. Rerata kadar asam laktat setelah perlakuan pada teknik massage effluarage (menggosok) yaitu $3,800 \pm 1,07$

3. Rerata kadar asam laktat setelah perlakuan pada teknik massage shaking (goncangan) yaitu $4,065 \pm 0,56$

4. Tidak ada perbedaan bermakna antara teknik massage effluarage (menggosok) dengan teknik massage shaking (goncangan) dengan nilai $p 0,416$ ( $p>0,05)$.

\section{SARAN}

Diharapkan pada penelitian selanjutnya dapat melanjutkan penelitian ini dengan menggunakan teknik-teknik massage yang lainnya. Sedangkan bagi siswa dan masyarakat aktivitas fisik dilakukan secara rutin, agar mendapat kebugaran secara biokimiawi kadar asam laktat yang lambat meningkat ditandai lambat lelah dan nyeri otot.

\section{DAFTAR PUSTAKA}

Adam, 2002. Pengaruh Kadar Ambang Batas Threshold Terhadap Latihan Anaerobik, diakses Desember 2014.

Ahmaidi,1996. Pengaruh Recovery Aktif Pada Kadar Asam Laktat Terhadap Latihan Anaerobik, Januari 2015.

Almuktabar. 2008. Perspektif Fisiologi Suatu Analisis Kelelahan. UPI. (http://www.iptekor.com/doc/11 2 1.pdf, diakses Maret 2015.

Bahartresna, Diana Aprilia.2005. Perbandingan Efek Pemulihan Aktif, Massage dan Pemulihan Pasif terhadap Penurunan Kadar Laktat Darah Tesis. Program Pascasarjana Universitas Padjadjaran. Bandung.

Bambang Priyonoadi. (2008). "Sport Massage". Yogyakarta: Fakultas IImu Keolahragaan Universitas Negeri Yogyakarta.

Bangsbo, et.all. 1995. Lactate and Ion $\mathrm{H}^{+}$ Effluxes From Human Scletal Muscle During Intense Dinamic Exercise. J. Phy. 46:115-133.

Battinelli T. 2000. Physique, Fitness and Performance. Florida : CRC Fress.

Best,T.M.Hunter 2008. Effectiveness of sport massage for recovery of Skeletal muscle from strenuous exercise. Clinical Journal of Sport Medicine.

Bompa and Fox. 1993. Power Training for sport (canada:Mosaic Pres). 
Bompa,Tudor.1994. Theory and Metodology of Training.lowa: Kendall Hunt Publishing Company.

Cafareli, E. And F. Flint 1992. The role of massage in preparation for and recovery from exercise. Sport Med

Callaghan, M. J. (1993). The role of massage in the management of the athlete: a review. British Medical Journal 27(1)

Clark, J.F,1997 dalam Hernawati.2006. Produksi Asam Laktat pada Exercise Aerobik dan Anaerobik, Jakarta: FMIPA UI

Cowie, Jourdain, Maisel. 2003, Clinical applications peptide testimg. Eur Heart

Destiana Ayu Ningrum,2012. Perbandingan Metode Hydrotherapy Massage Dan Massage Manual Terhadap Pemulihan Kelelahan Pasca Olahraga Anaerobik Lactacid. Universitas Pendidikan Indonesia.Jakarta

Departemen Kesehatan RI. 2006. Petunjuk Teknis Pengukuran kebugaran Jasmani. Jakarta.

Feriyati, Fera. 2006. Anatomi Sistem Saraf dan Peranannya dalam Kontraksi Otot. (http://repository.usu.ac.id/bitstream/12345 6789/3509/1/06001194.pdf).

Foss ML. SJ. 1998. Fox's physiological basis for exercise and sport. $6^{\text {th }}$ ed. Boston: The McGraw-Hill Co.

Fox, E.L., Bowers, R.W., Foss, M.L. (1993) The Physiological Basis For Exercise And Sport, USA, Brown \& Benchmark Publ

Ganong, FW. 2003. Buku Ajar Fisiologi Kedokteran. Edisi 20. Jakarta. EGC.

Germinari, E., et.al. 2004. Effect of Modulator Sarcoplasmic $\mathrm{Ca}^{2+}$ Release on the Development of Skeletal Muscle Fatigue. J. Apply Phy., 96:645-649.

Giam dan Teh. 1992. IImu Kedokteran Olahraga. Bina Rupa Aksara, Jakarta, Indonesia.

Gladden, L.B. and Spriet. 1990. The Role Of Skletal Muscle in Lactate Exchange During Exercise. J. Med and Sci. 29 : 205212.
Gleim GM, McHugh MP. Flexybility and its effect on sports injury and performance. Sport Med. 1999.

Goats, G.C. 1994. Massage the scientific basis of an ancient art : Part 1. The techniques. British Journal of Sports Medicine.

Guyton, A.C. 1999. Buku Ajar Fisiologi Kedokteran.

Edisi ke-9. Jakarta.EGC

Guyton, Arthur. 2008. Buku Ajar Fisiologi Kedokteran/Arthur, Guyton, John E.Hall;alih bahasa, Irawati et al, Jakarta: EGC

Halliwell, B. \& Whiteman, M. 1999. Measuring reactive species and oxidative damage in vivo and in cell culture: how should you do it and what do the results mean? $\mathrm{Br} \mathrm{J}$ Pharmacol, 142, 231-55

Harsono, 1988. Coaching Dan Aspek-aspek Psikologis Dalam Coaching. Jakarta: Dekdikbud Dirjen Dikti

Hemmings, B., et al. (2000). Effects of massage on physiological restoration,perceived recovery, and repeated sports performance. British Journal of Sports Medicine 34(2): 109.

Heyward VH. 1991. Advance fitness assessment and exercise prescription. $3^{\text {rd }}$ ed. Champaign (IL) : Human Kinetic.

Irawan, Anwari. 2007. Metabolisme Energi tubuh dan olahraga. Sport Science Brief. http://www.pssplab.com/journal/06.pdf. Diakses 1 April 2011.

Ismunandar. 2005. Rahasia Kecepatan Atlet Lari. Departemen Kimia, F.MIFA ITB,(http://www.kimia net.lipi.go.id).

Janssen, Petter GLM. 1987. Training lactat pulse rate, oule Finland: folar electroy

Jeremy Ward. (2009). At a Glance Fisiologi.

Penerjemah: Indah Retno Wardani. Jakarta: Erlangga.

Junusul Hairy. (1989). Fisiologi Olahraga Jilid I. Jakarta: Depdikbud.

Karyono,2006. Pengaruh Kadar Asam Laktat Terhadap Latihan Anaerobik, di Akses Maret 2015. 
Kisner \& Lyrin, 1996. Therapeutic Exercise Foundation \& Tecniques, Third Edition. Philadelphia.

Krismadi, W. 2002. Kontrol dan Pemanfaatan Asam laktat Dalam Peningkatan Prestasi Olahraga. Palembang: Jurnal Kesehatan UNSRI

Laurentia, M. 2003. Nutrisi dan Sistem Penyediaan Energi. J. Kes, 4 : 50-57.

Lea \& Febiger. 1996. Basic Biomecanics Of The Muskuloskletal System. Second Edition. Philadelphia. London.

Livingstone, Churchill, $1998 . \quad$ Sport Physiotherapy Applied Science \& Practice.

Martin, N.A., R.F.Zoeller, R.J.Robertson and S.M.Lephant 1998. The comparative effects of sport massage, active recovery, and rest in promoting

Moston, Muska 1997. Teaching Physical Education, ohio: Charles E. Meribt Publishing Company

Novita, Intan 2014. Massage dan Prestasi atlet. http://www.scrib.com/doc/21070759/massag $\underline{\mathrm{e}}$ dan prestasi atlet, di akses pada Maret 2015.

Patellongi, Ilhamjaya. 2000. Fisiologi Olah Raga. Makasar: Bagian IImu Faal, Fakultas Kedokteran Universitas Hasanuddin

Platzer W. 1991. Atlas dan Buku Teks Anatomi. Diterjemahkan : Adji Dharma. Jakarta : EGC

Prentice WE. 1994. Rehabilitaion techniques in sport medicine. $2^{\text {nd. }}$ St. Louis (MA): MosbyYear Book.

Pradana, Dhoani Ardi 2011. Ambang Anaerobik. Diakses

dari http://www.scrib.com/doc/67486/Ambang Anaerobik

Prasetyo,Yudik. 2008. Pengaruh massage teknik friction pada tungkai setelah latihan fisik submaksimal terhadap kecepatan pembuangan laktat darah. Diakses dari http://www.ADLNPerpustakaanUniversitasAir langga/surabya Maret 2015

Rahmawati, 2012. Massage. Diakses dari http://www.scrib.com/doc/08/massage Maret 2015
Robert, S.R. 1999. Exercise Physiology; Exercise, Performance and Clinical Application. St. Louis. Mosby.

Scott, P.K. \& Howley, E.T. 2002. Exercise Physiology; Theory and Application to Fitness and Performance. Boston. Mc Graw Hill.

Sri Martini, 2014. Pengaruh massage pasca latihan fisik anaerobik terhadap kadar asam laktat pada orang tidak terlatih.Fakultas kedokteran Unsri.

Subardjah. Latihan Kondisi Fisik. http://file.upi.edu/Direktori/F\%20\%20FPOK/JUR.\%20PEND.\%20OLAHRAGA 196506141990011\%20-20YUNYUN \%20YUDIANA/Latihan\%20Kondisi\%20Fisik. pdf. Diakses Maret 2015

Sugiharto, 2012. Penurunan asam laktat pada fase pemulihan aktif dengan Argocycle selama 5 menit. Jurnal Media IImu Keolahragaan Indonesia. Diakses Maret 2015

Sugiyono, 2009. Metode penelitian Kualitatif dan Kuantitatif. Bandung : Alfa Beta

Sukirno, 2012. Dasar-dasar atletik dan latihan fisik. Palembang: UNSRI

Sukirno, 2015. Massage dan Cedera Olahraga. Palembang: UNSRI

Yayuk, 2014. Fisiologi Latihan. Diakses dari http://www.scrib.com/doc/21070759/fisiologi -latihan, pada tanggal desember 2014.

Vander at al, 2001. Fisiologi latihan. Di akses dari

http://repository.usu.ac.id/bitstream/123456 789/29073/4/Chapter\%20II.pdf, tanggal desember 2014. 